\title{
THE DISPLACEMENT OF NATIVE ANT SPECIES BY THE INTRODUCED ARGENTINE ANT IRIDOMYRMEX HUMILIS MAYR*
}

\author{
By James M. Erickson \\ Department of Entomology and Limnology \\ Cornell University, Ithaca, New York 14850 \\ INTRODUCTION
}

Many authors have described how Iridomyrmex humilis Mayr has become a major pest throughout the world (Brun, 1924; Zimmerman, 1940; Smith, 1947; Morley, 1953; Skaife, 1961; Pasfield, I968). Once these ants become established in a locality they will not tolerate the existence of any other species of ants, and as the populations of each colony build up in density, they emigrate in all directions, consolidating as they go and driving other species before them. Not only does I. humilis displace native ant species, but it has been shown to displace other introduced tramp species. The ant Pheidole megacephala $\mathrm{F}$. is apparently a native to Africa and has been spread by commerce to almost all of the more humid parts of the world. It too is a serious pest and displaces native species. However, in 1852 , in Funchal, the capital of Madiera, this species was itself displaced by $I$. humilis (Stoll, I 898; Wheeler, 1906). The displacement of $P$. megacephala by $I$. humilis has also been observed in the Hawaiian Islands (Wilson and Taylor, 1967; Fluker and Beardsley, 1970) and in Bermuda (Haskins and Haskins, 1965; Crowell, I968). Wilson (I95I) reports that a local naturalist in Mobile, Alabama observed I. humilis displacing the imported fire ant Solenopsis saevissima richteri Forel, and Fluker and Beardsley ( 1970) reported the displacement of $S$. geminata F. in Hawaii.

Shapley (I920 a, b) describes an "intermittent war" between $I$. humilis and the native California species which he feels would eventually eliminate most of the native ant species. Tulloch (1930) and Michener (1942) described the displacement of the California harvester ant Pogonomyrmex californicus by $I$. humilis.

\section{Methods AND Materials}

In the present study, the displacement of three ant species, $P$. californicus Buckley, Pheidole grallipes Wheeler, and Veromessor pergandei Mayr, by I. humilis was observed for a six year period. Detailed observations of the displacement of $P$. californicus were

*Manuscript received by the editor March 2, 1972 


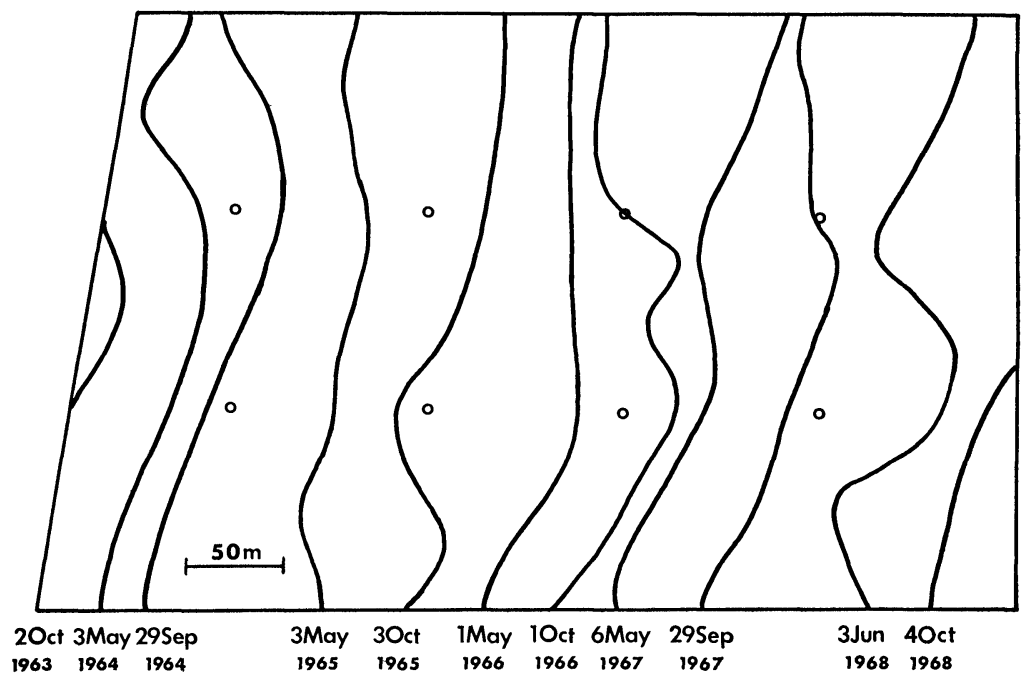

Figure 1. The forward advance of $I$. humilis as it displaces $P$. californicus in an old field from October 1963 to October 1968. Reference markers are located at intervals of 100 meters (o).

made at six month intervals, whereas only minor observations were made of the other two species. Studies were carried out in an old field from May 1963 to October 1968 in San Luis Rey, California, two miles east of Oceanside in San Diego County. The study field consisted primarily of sandy soil with Bromus rubens, Salsola kali, Sonchus olcraceous, Heliotropium curassauicum, and Brassica nigra, the dominant plants. The study area was almost rectangular, being 300 meters wide by 500 meters long on the south side and 450 meters long on the north side. The total area of the field was 14.25 hectares. The field was bordered by California Highway 78 on the west, dirt field roads on the east and south, and by a grass lawn on the north. Two additional fields of $5(2 \mathrm{~A})$ and $7(2 \mathrm{~B})$ hectares were located at the southern edge of the main study field. Here studies on colony size, foraging distance, and food preference were carried out (Erickson, 1972 ; and in manuscript).

All colonies of $P$. californicus and $I$. humilis were individually marked with color-coded wooden stakes placed one meter from the colony entrance. At intervals of approximately six months the position of each colony was noted on a large map, measured to the nearest one meter from the colony entrance using the reference 


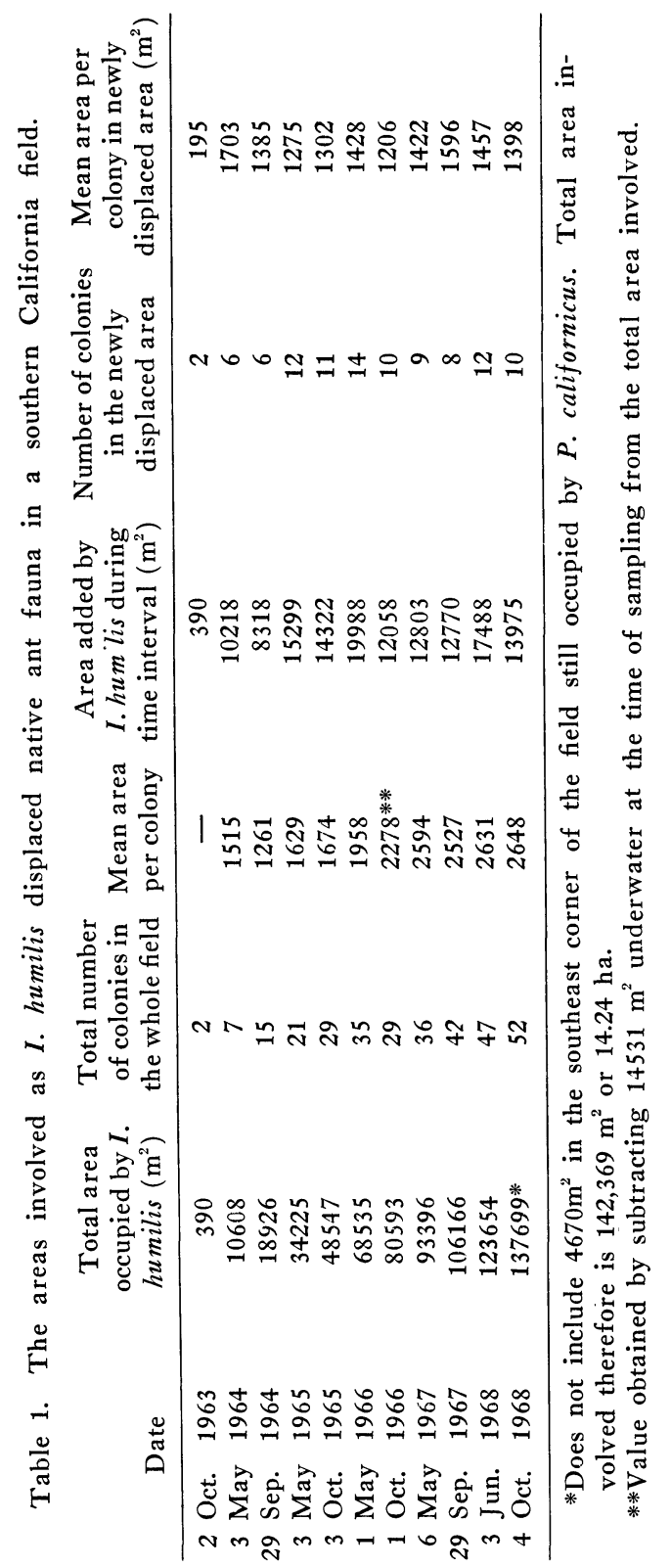


markers placed at IoO meter intervals throughout the field (see Fig. I). The lines on Fig. I deliniate the limit of eastward expansion of $I$. humilis colonies at the time the survey was taken. The new area added was then calculated by subtracting the total occupied area at the previous sampling date from the new total area occupied by I. humilis. This area was then divided by the number of colonies in the new added territory to get the mean area per colony values. At the same time, quadrat sampling with 30 randomly placed 2 meter by 2 meter quadrats were carried out to determine the vegetation characteristics. Weather data were taken from a station 3 miles northeast of the field site and averaged to get monthly mean temperatures and precipitation.

\section{RESULTS}

The displacement of the three other ant species by $I$. humilis started slowly in October, I963, but increased to an almost constant rate from 3 May ig64 to 4 October I968 (Table I, Fig. I). The new area added by $I$. humilis during each displacement interval of six months was approximately $\mathrm{I} 4000 \mathrm{~m}^{2}$ ranging from $8318 \mathrm{~m}^{2}$ to $19988 \mathrm{~m}^{2}$ in the study field. The mean area per colony of $I$. humilis for the whole occupied portion of the field increased during each sampling interval, whereas the mean area per colony in the newly displaced land was almost a constant $\mathrm{I} 400 \mathrm{~m}^{2}$ per colony. The number of colonies of $I$. humilis increased during each displacement interval as the displacement proceeded whereas the number of colonies of $P$. californicus decreased except for a minor fluctuation due to flooding between 3 October I965 and I May I966 (Fig. 2). By October 1968, not a single colony of $P$. grallipes was observed in the study field, and by 5 March 1969 all colonies of $P$. californicus and $V$. pergande $i$ were located outside the boundaries of the study field. In their place remained 57 colonies of 1 . humilis.

\section{Discussion}

To explain this phenomenon of displacement, some comparison is necessary of the basic biology of the ant species involved. The nests of $I$. humilis are situated wherever there is sufficient moisture and where light is excluded, as under rocks and logs (Woodword, I905, I9IO; Eckert and Mallis, I937, Smith, 1947) or in shallow nests in the soil (Cook, I953). These ants occur in a wide variety of habitats - swamps, beaches, lawns and gardens, roadsides, houses, and various woodlands (Crowell, 1968). I. humilis are exceptionally restless ants and normally emigrate one or more times a season in search 


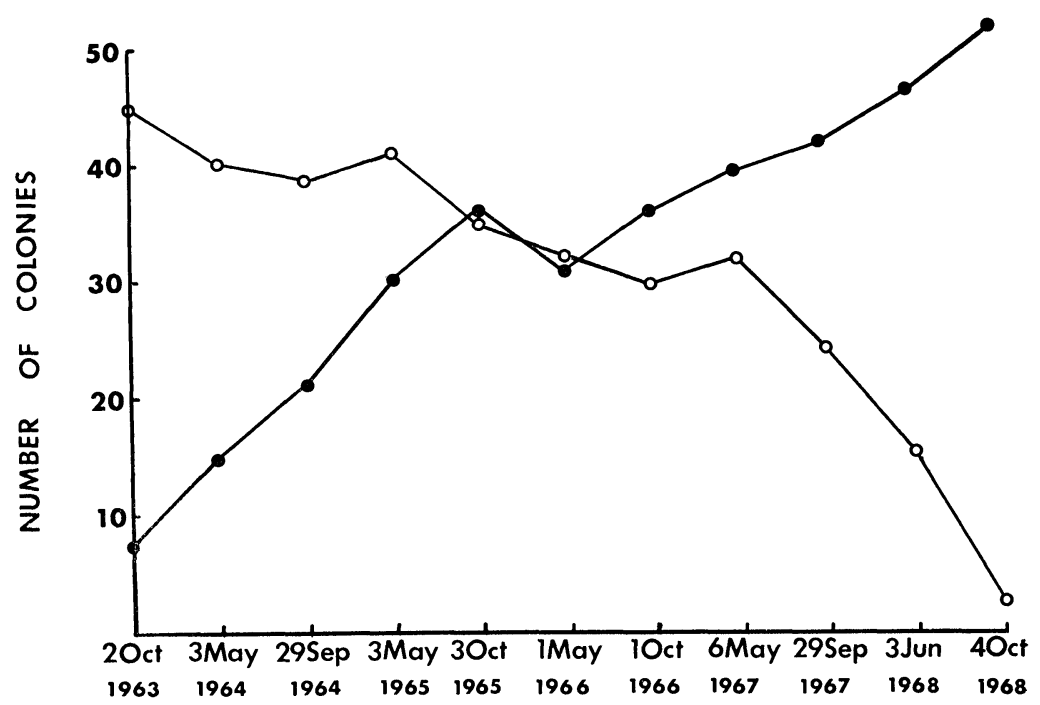

Figure 2. The number of colonies in the entire field of P. californicus (o) and 1 . humilis $(\bullet)$ from October 1963 to October 1968.

of more favorable habitats (Wilson, I97 I). Colonies of $I$. humilis contain a large number of queens with thousands of workers (Smith, 1947) and proliferate by swarming of detachments of workers who accompany secondary queens out of the nest (Wheeler, 1933; WynneEdwards, 1963; Crowell, 1968). They are highly omnivorous but tend to seek sweet or fatty foods (Eckert and Mallis, 1937; Creighton, I960; Cook, I953), and tend aphids and scale insects in orchards and gardens (Skaife, I96I).

In contrast with $I$. humilis, the California harvesters are large ants (4-6 mm long) which are primarily seed gatherers, but are also known to be slightly omnivorous (Van Pelt, 1966). Colonies of $P$. californicus are small in comparison to $I$. humilis and contain only one queen. Proliferation takes place by large swarms of winged reproductives. The California harvester ant tends to nest in dryer semi-desert habitats and can tolerate much higher temperatures than I. humilis (Wheeler, 1926; Cole, 1932, 1968; Michener, 1942; Erickson, 1972).

The relative reproductive potential of $I$. humilis is probably much higher than P. californicus. This is most likely due to the large num- 
ber of queens in each colony, the method of colony proliferation, and the omnivorous habits of these ants. These factors may also account for the great and rapid spread of $I$. humilis throughout the temperate regions of the world.

Basic differences in food resources limit to some extent the amount of competition between $I$. humilis and the three harvester ant species (Table 2). I. humilis is highly omnivorous whereas the three harvester ant species are only slightly omnivorous, being basically seed gatherers. I. humilis not only monopolizes the proven food sources but attempts to control the remaining foraging areas (Wilson, I97I). In the main study field, food, especially seeds, were very abundant. The food chambers of $P$. californicus and $I$. humilis were always full when the colonies were excavated. In fields $2 \mathrm{~A}$ and $2 \mathrm{~B}$, the area was supplemented with approximately five pounds of mixed grass seed per month to determine the foraging characteristics and distances for $P$. californicus. The seeds, colored with common food coloring, were fully acceptable to the ants, making up 43 to $59 \%$ of the P. californicus food stores and 9 to $17 \%$ of the 1 . humilis food stores. The variously colored seeds were spread in concentric circles from a nest of $P$. californicus every 5 meters to a distance of 30 meters. The maximum foraging distance for $P$. californicus was about ro meters except in areas where there was an $I$. humilis colony in which case the harvester ants foraged no farther than 5 meters even though the I. humilis colony was 20 meters away. Even though both fields were supplemented with a little over 50 pounds of mixed grass seed per year, in one year $P$. californicus was displaced 76 meters (2A) and 109 meters $(2 \mathrm{~B})$ by $I$. humilis. It does not appear that this displacement is due to any overlap of a fundamental food dimension.

At each sampling interval the mean area per colony of $I$. humilis in the newly displaced territory was approximately $1400 \mathrm{~m}^{2}$ whereas the mean area per colony for the entire field increased from $1400 \mathrm{~m}^{2}$ to approximately $2600 \mathrm{~m}^{2}$ during the five year period (Table $\mathrm{I}$ ). There thus appears to be a minimal area for a colony of $I$. humilis in the newly acquired areas and as these colonies become established and increase in population density, the colony requires a larger area.

Michener (1942) working with $P$. californicus encountered a similar displacement by $I$. humilis. He described in detail how individual harvester ants would be set upon and killed by groups of I. humilis. When temperatures are cool, Pogonomyrmex species tend to be sluggish and it is at this time that the Argentine ants torment the harvester ants as they forage around the nest (Michener, 1942). 
Table 2. Food resources of $I$. humilis compared with species it has displaced throughout the world.

\begin{tabular}{|c|c|c|c|}
\hline Species & $\begin{array}{ll}\text { Main } & D \\
\text { Food Source } & \text { Or }\end{array}$ & $\begin{array}{l}\text { Degree of } \\
\text { Omnivory }\end{array}$ & Reference \\
\hline Iridomyrmex humilis Mayr & $\begin{array}{l}\text { sweet or fatty } \\
\text { foods, tends } \\
\text { aphids scale } \\
\text { insects, grains }\end{array}$ & +++ & $\begin{array}{l}\text { Wheeler, } 1910 \\
\text { Eckert \& } \\
\text { Mallis, } 1937 \\
\text { Creighton, } 1950 \\
\text { Skaife, } 1961\end{array}$ \\
\hline $\begin{array}{c}\text { *Pogonomyrmex californicus } \\
\text { Buckley }\end{array}$ & seed gatherers & + & $\begin{array}{l}\text { Wheeler, } 1910 \\
\text { Forel, } 1928 \\
\text { Wildermuth \& } \\
\text { Davis, } 1931 \\
\text { Cook, } 1953 \\
\text { Van Pelt, } 1966 \\
\text { Cole, } 1968\end{array}$ \\
\hline Phe.do'e megacephala F. & $\begin{array}{l}\text { sweet or fatty } \\
\text { foods }\end{array}$ & +++ & $\begin{array}{l}\text { Wheeler, } 1910 \\
\text { Forel, } 1928\end{array}$ \\
\hline *Pheidole grallipes Wheeler & seed gatherers & + & $\begin{array}{l}\text { Eckert \& } \\
\text { Mallis, } 1937 \\
\text { Cook, } 1953\end{array}$ \\
\hline *Veromessor pergandei Mayr & seed gatherers & + & $\begin{array}{l}\text { Eckert \& } \\
\text { Mallis, } 1937 \\
\text { Cook, } 1953\end{array}$ \\
\hline Solenopsis saevissima Forel & $\begin{array}{l}\text { insects, fruits, } \\
\text { grains, flowers, } \\
\text { vegetables }\end{array}$ & ++ & $\begin{array}{l}\text { Creighton, } 1950 \\
\text { Cook, } 1953\end{array}$ \\
\hline Solenopsis geminata $\mathrm{F}$. & $\begin{array}{l}\text { insects, fruits, } \\
\text { grains }\end{array}$ & ++ & $\begin{array}{l}\text { Creighton, } 1950 \\
\text { Fluker \& } \\
\quad \text { Beardsley, } 1970\end{array}$ \\
\hline
\end{tabular}

*Displaced in present study.

$+++=$ highly omnivorous; $++=$ moderately omnivorous; $+=$ slightly omnivorous

Should a harvester ant come upon an Argentine ant during the warmer parts of the day, the former grasps the smaller ant with its mandibles and stings it to death (Michener, 1942). At dawn, sunset, or on a cloudy day the Argentine ants will attack and cling to the mandibles, legs, and antennae of the harvester ants and attempt to kill the larger ant. Observations made in the present study confirm Michener's discussion of the aggressive actions between the species.

There were no significant differences in the mean monthly temperature or precipitation from month to month (i.e. - all the Januarys, etc.) over the course of the study. The vegetation studies 
similarly showed that there was no significant difference in the order of dominance of the six plants mentioned. It does not appear that $P$. californicus ameliorates the habitat as it does not clear vegetation as many harvester ant species do. I. humilis does not utilize the same nest sites as the displaced species and in fact, not a single $I$. humilis colony was found within two meters of an abandoned harvester ant colony.

Pasfield ( I968) found I. humilis displaced its neighbors at a maximum rate of 274 meters (300 yards) per year in Australia. This value is higher than the IOO to 200 meters per year at Fort Shafter on the island of Oahu between 1940 and 1944 (Pemberton, 1944) or the average of 100 meters per year in the present study (Fig. I). Fluker and Beardsley ( 1970) observed I. humilis displace P. megacephala in Hawaii at about 66 to Ioo meters per year. All these values seem low when compared to the displacement rate of 8 kilometers ( 5 miles) per year for native species by the fire ant $S$. saevissima in the Gulf states (Wilson and Brown, I957).

The effectiveness of competition in nature is best demonstrated by the impact of an invading species on the native fauna. It appears that here, there is a tremendous competition for nest space, which is the general case for highly aggressive territorial ant species such as Pheidole, Solenopsis, and Iridomyrmex (Wilson, I97I). Three aspects of the populations biology of $I$. humilis gives this species a distinct competitive advantage over the native harvester ants. The general aggressive nature of $I$. humilis as well as the large number of queens and method of proliferation allow these ants to move in and establish new colonies in a very short time. Raiding columns of workers clear the way and pioneer groups of workers and queens follow into freshly opened nest areas.

\section{Acknowledgements}

I would like to thank my uncle, Mr. Carl Erickson, for the generous use of his property and to my cousins, Bob, Tom, David, and JoAnn for their assistance in various aspects of the study. Thanks are also due to Mrs. Mudie of the Department of Botany at San Diego State College for determination of the plant species and Dr. A. C. Cole, Jr. of the University of Tennessee for identification of the ant species. Mr. F. Slansky, Jr. and Drs. W. L. Brown, Jr., R. G. Helgesen, and P. P. Feeny read the manuscript and gave many helpful comments. A grant from the Grace Griswold Fund assisted with the publication costs. 
BRUN, R.

\section{Literature Cited}

1924. Das Leben der Ameisen. B. G. Teubner, Leipzig. $211 \mathrm{pp}$.

Cole, A. C., JR.

1932. Notes on the ant Pogonomyrmex californicus Buckley (Hym: Formicidae). Entomol. News 43: 113-115.

1968. Pogonomyrmex harvester ants. A study of the genus in North America. University of Tennessee Press, Knoxville. 222 pp.

Cook, T. W.

1953. The ants of California. Pacific Books. Palo Alto, California. $462 \mathrm{pp}$.

Creighton, W. S.

1950. The ants of North America. Bull. Mus. Comp. Zool. Harv., 104. Cambridge, Mass. 568 pp.

Croweli, K. L.

1968. Rates of competitive exclusion by the Argentine ant in Bermuda. Ecology 49: 551-555.

Eckert, J. E. ANd A. Mallis

1937. Ants and their control in California. Cal. Agric. Exp. Sta. Circ. 3.42 .

Erickson, J. M.

1972. Mark-recapture techniques for population estimates of Pogonomyrmex ant colonies: An evaluation of the $\mathrm{P}^{32}$ technique. Ann. Ent. Soc. Amer. 65: 57-61.

Fluker, S. S. AND J. W. Beardsley

1970. Sympatric associations of three ants: Iridomyrmex humilis, Pheidole megacephala and Anoplolepis longipes in Hawaii. Ann. Ent. Soc. Amer. 63 : 1290-1296.

FOREL, A.

1928. The social world of the ants compared with that of man. G. P. Putnam's and Son's, Ltd. London. $445 \mathrm{pp}$.

Haskins, C. P. AND E. F. Haskins

1965. Pheidole megacephala and Iridomyrmex humilis in Bermuda Equilibrium or slow replacement? Ecology 46: 736-740.

Michener, C. D.

1942. The history and behavior of a colony of harvester ants. Sci. Monthly 55: 248-258.

Morley, D. W.

1953. The ant world. Penguin Books, Ltd. London. 191 pp.

NEWELL, W.

1908. Notes on the habits of the Argentine ant or "New Orleans" ant, Pasfield, G.

Iridomyrmex humilis Mayr. Jour. Econ. Ent. 1: 21-34.

1968. Argentine ants. Aust. Natur. Hist. 16: 12-15.

Pemberton, C. E.

1944. (Notes and exhibitions). Proc. Hawaiian Entomol. Soc. 12: 25. SHAPLEY, $\mathrm{H}$.

1920a. Preliminary report on Pterergates in Pogonomyrmex californicus. Proc. Nat. Acad. Sci. 6: 687-690.

1920b. Notes on Pterergates in the California harvester ant. Psyche 27 : 72-74. 
SKAIFE, S. H.

1961. The study of ants. Spottiswoode, Ballantyne, and Co. Ltd. London. $178 \mathrm{pp}$.

SMITH, M. R.

1947. A generic and subgeneric synapsis of the United States ants, based on the workers (Hym: Formicidae). Amer. Mid. Natl. 37 : 521-647.

STOLL, O.

1898. Zur kenntnis der geographischen verbreitung der maeisen. Mitt. Schweiz. Entomol. Ges. 10:120-126.

Titus, E. S. G.

1905. Report on the "New Orleans" ant Iridomyrmex humilis Mayr. U. S. Dept. Agr. Bur. Ent. Bull. 52: 79-84.

TUlloch, G. S.

1930. An unusual nest of Pogonomyrmex. Psyche 37:61-70.

Van Pelt, A. F.

1966. Activity and density of old field ants on the Savannah River Plant, South Carolina. J. Elisha Mitchell Sci. Soc. 82: 35-43.

WHEELER, W. M.

1906. On certain tropical ants introduced into the United States. Entomol. News 17: 24.

1926. Ants: their structure, development and behavior, ed. 3. Columbia Univ. Press. New York. 566 pp.

1933. Colony founding among ants. Harvard Univ. Press. Cambridge, Mass. $179 \mathrm{pp}$.

Wildermuth, V. L. AND E. G. Davis

1931. The red harvester ant and how to subdue it. U. S. Dept. Agr. Farm. Bull. No. 1668. 21 pp.

Wilson, E. O.

1951. Variation and adaptation in the imported fire ant. Evolution 5: 68-79.

1971. The insect societies. Harvard University Press. Cambridge, Mass. $548 \mathrm{pp}$.

Wilson, E. O. AND W. L. Brown, JR.

1957. Recent changes in the introduced population of the fire ant Solenopsis saevissima. Evolution 12: 211-218.

Wilson, E. O. ANd R. W. TAYlor

1967. The ants of Polynesia. Pacific Insects Monogr. 14. Bishop Museum, Honolulu, Hawaii.

WOODWORD, E. W.

1905. The Argentine ant in California. Cal. Agr. Exp. Sta. Circ. 38.

1910. The control of the Argentine ant. Cal. Agr. Exp. Sta. Bull. 207.

WYNNE-EDWARDS, V. C.

1963. Animal dispersion in relation to social behavior. Oliver and Boyd. London. $653 \mathrm{pp}$.

Zimmerman, E. C.

1940. The Argentine ant in Hawaii. Proc. Hawaiian Ent. Soc. 11: 108. 

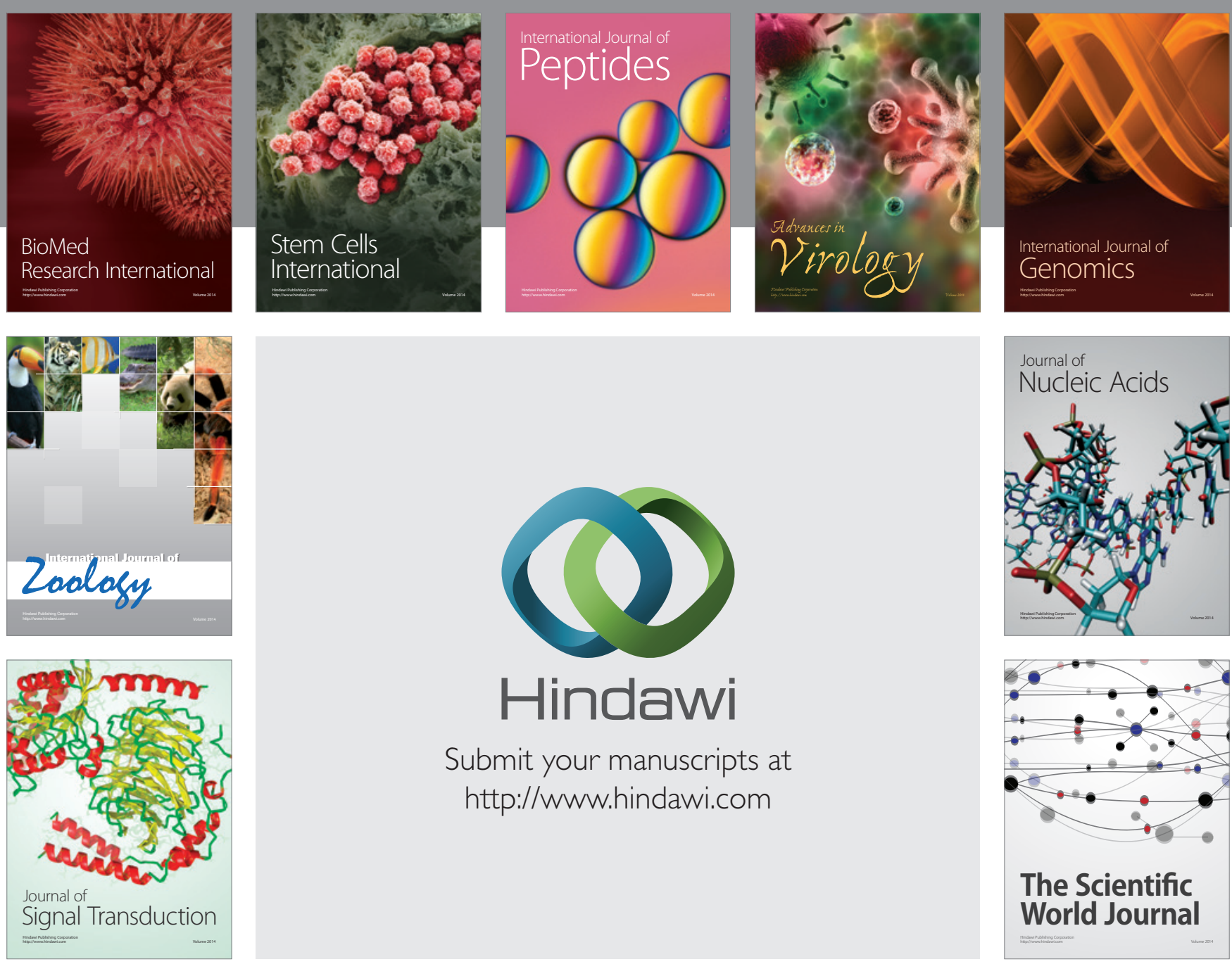

Submit your manuscripts at

http://www.hindawi.com
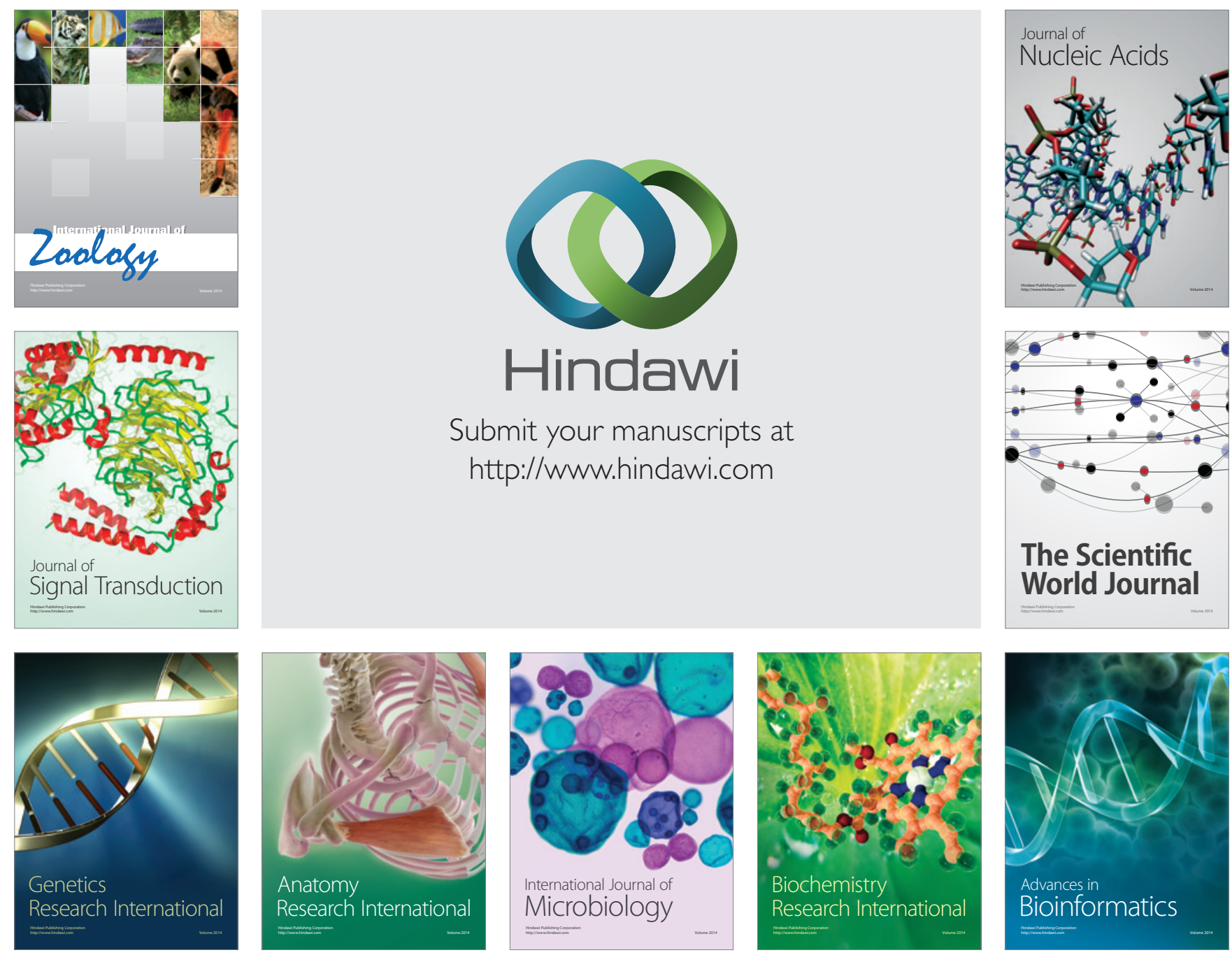

The Scientific World Journal
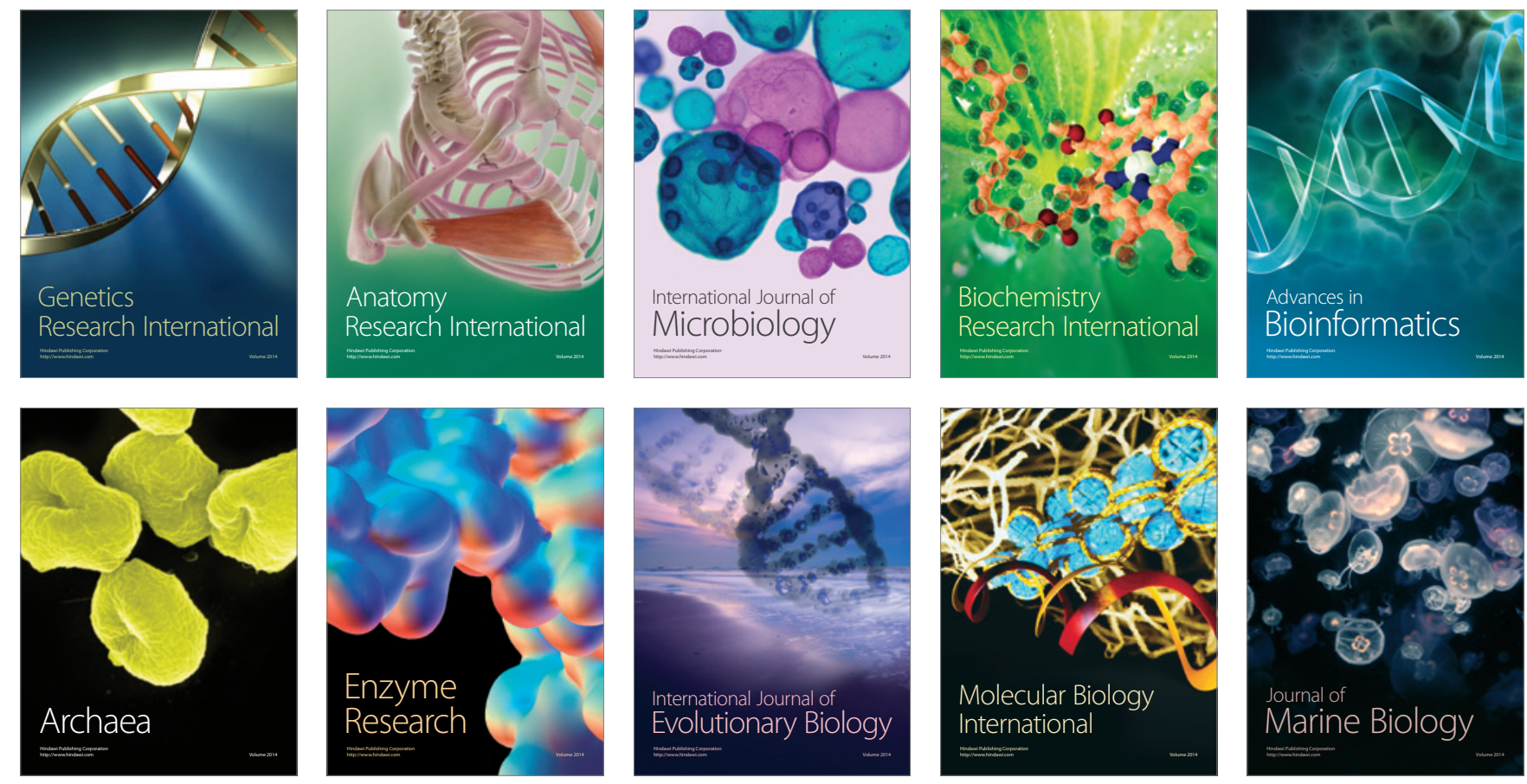